\title{
Purification, localization, properties and regulation of glutamine synthetase from Hyphomicrobium X
}

\author{
M. G. Duchars $\nmid$ and Margaret M. AtTWOOD* \\ Department of Molecular Biology and Biotechnology, University of Sheffield, Western Bank, Sheffield S10 2TN, UK
}

(Received 15 October 1990; revised 30 January 1991; accepted 26 February 1991)

\begin{abstract}
The purification, location, properties and regulation of glutamine synthetase (GS) from the facultative methylotroph Hyphomicrobium $\mathrm{X}$ were investigated. The enzyme was purified to homogeneity by differential centrifugation, Blue Sepharose CL-6B chromatography and Sephadex G-25 gel filtration. The specific activity of the purified enzyme was $44.7 \mu \mathrm{mol} \mathrm{min}^{-1}$ (mg protein) $^{-1}$. GS was cytoplasmic in location with no direct association with DNA, membranes or the enzyme glutamine:2-oxoglutarate aminotransferase (GOGAT). The molecular mass of the native enzyme was $638 \mathrm{kDa}$; it was composed of 12 subunits of molecular mass $53 \mathrm{kDa}$. Double reciprocal plots showed that the enzyme followed Michaelis-Menten kinetics. The apparent $K_{\mathrm{m}}$ values for hydroxamate and glutamine in the $\gamma$-glutamyl transferase assay were 7.0 and $5.0 \mathrm{mM}$ respectively; those of ammonia, glutamate and ATP in the biosynthetic assay were $0 \cdot 032,31 \cdot 1$ and $0.37 \mathrm{mM}$ respectively. GS activity was controlled by covalent modification, the presence of specific divalent cations and feedback inhibition by several end-products of glutamine metabolism.
\end{abstract}

\section{Introduction}

Hyphomicrobium $\mathrm{X}$ is a facultative methylotroph which utilizes ammonium nitrogen as the preferred nitrogen source but can use nitrate and organic nitrogen, in particular, methylamine (Harder \& Attwood, 1978; Brooke et al., 1987). Irrespective of the primary source, nitrogen is assimilated into biomass via the intermediates glutamine and glutamate. There are two major pathways whereby nitrogen assimilation occurs in bacteria: one pathway functions under conditions of excess ammonium by utilizing the activity of an NADPH-dependent glutamate dehydrogenase and the other under conditions of ammonium limitation and involves the combined action of two enzymes, glutamine synthetase (GS) and glutamate:2-oxoglutarate aminotransferase (GOGAT). Both of these pathways have been reviewed extensively (Tyler, 1978; Dalton, 1979; Brown, 1980) and shown to be expressed in Hyphomicrobium X (Brooke et al., 1987).

The most detailed studies on GS/GOGAT have focused on GS activity in Escherichia coli (Ginsburg \& Stadtman, 1973; Tempest et al., 1973). The ability of GS

$\dagger$ Present address: ICI Biological Products, PO Box 1, Billingham, Cleveland, UK.

Abbreviations: GS, glutamine synthetase; GOGAT, glutamate:2oxoglutarate aminotransferase. to form a coupling reaction with GOGAT, together with its low $K_{\mathrm{m}}$ for ammonia, enables ammonium nitrogen to be assimilated when low concentrations are present in the environment. Moreover, GS responds to changes in the concentration of ammonia available. The activity levels are regulated by a complex control system which results in extremely rapid and precise responses to changes in the nitrogen status within the cell. When the ammonia concentration is high, GS loses its ability to form glutamine in the biosynthetic reaction

$$
\text { L-Glutamate }+\mathrm{NH}_{3}+\mathrm{ATP} \underset{\text { L-glutamine }+\mathrm{ADP}}{\stackrel{\left[\mathrm{Mg}^{2+}\right]}{\longrightarrow}}
$$

although the enzyme retains activity in the artificial assay

$$
\begin{aligned}
\text { L-Glutamine }+\mathrm{NH}_{2} \mathrm{OH} & \underset{\left[\mathrm{Mn}^{2+} \text { or } \mathrm{Mg}^{2+}\right]}{[\text { aDP, arsate }]} \\
\gamma \text {-glutamylhydroxamate }+\mathrm{NH}_{3} & (2)
\end{aligned}
$$

This rapid decrease in ability to form glutamine in reaction (1) is due to the attachment of adenylyl groups to the enzyme. This addition of up to 12 molar equivalents of AMP to the enzyme is reversible and due to the covalent attachment of AMP to a specific tyrosyl residue on each subunit in the enzyme structure (Kingdom et al., 1967; Wulff et al., 1967). This adenylylation process is now known to be controlled via a complex cascade 
system involving the enzymes adenyltransferase, uridyltransferase and a regulatory protein (PII) which occurs in two forms, PIIA and PIID (Stadtman et al., 1970; Shapiro \& Stadtman, 1970; Ginsburg \& Stadtman, 1973). Indeed, the adenylylation state of the enzyme can be altered to a specific level in vitro by incubation of GS with adenyltransferase, PII, and various effectors including ATP, UTP, $\mathrm{P}_{\mathrm{i}}, 2$-oxoglutarate, glutamine and $\mathrm{Mg}^{2+}$ or $\mathrm{Mn}^{2+}$. The final adenylylation state obtained is dependent not only on the ratio of PIIA : PIID, but also on which effectors are present and their concentration (Segal et al., 1974). The adenylylation state has a considerable effect on the enzyme activity, resulting in changes in the $K_{\mathrm{m}}$ and $V_{\max }$ values as well as the $\mathrm{pH}$ optimum, divalent cation specificity and inhibitory properties (Ginsburg, 1969; Ginsburg et al., 1970). The presence of certain divalent cations is essential for catalytic activity. In the absence of any divalent cation the GS is 'relaxed' and the structure less compact, the -SH groups are exposed and the enzyme is more susceptible to disaggregation (Shapiro \& Stadtman, 1967). When GS in this form is incubated with divalent cations the $-\mathrm{SH}$ groups become buried in the enzyme structure and the catalytic activity is restored (Kingdom et al., 1968; Valentine et al., 1968; Segal \& Stadtman, $1972 b$ ). It has been demonstrated, using the $\gamma$-glutamyltransferase assay (reaction 2), that GS is specific in the metal ion requirement for activity: $\mathrm{Mn}^{2+}$ supports the activity of both adenylylated (biosynthetically inactive) and deadenylylated (biosynthetically active) enzyme although the $\mathrm{pH}$ optimum varies considerably with the state of adenylylation. Addition of $\mathrm{Mg}^{2+}$ to the $\mathrm{Mn}^{2+}$ dependent transferase assay inhibits the activity of the adenylylated subunits only (Shapiro \& Stadtman, 1970; Stadtman et al., 1970). This is used to measure the relative adenylylation state of the enzyme by comparing the activity in the presence of $\mathrm{Mn}^{2+}$ with the activity in the presence of $\mathrm{Mn}^{2+}$ and $\mathrm{Mg}^{2+}$.

A second method of GS regulation involves cumulative feedback inhibition by the endproducts of glutamine metabolism (Woolfolk et al., 1964; Hubbard \& Stadtman, 1967a; Kleinschmidt \& Kleiner, 1978). This appears to be the only regulatory mechanism to control GS activity in those organisms for which adenylylation control has not been demonstrated (Deuel \& Stadtman, 1970; Wedler et al., 1976).

Although the presence of GS has been reported in methanotrophs (Shishkina \& Trotsenko, 1979) and in methylotrophic bacteria (Loginova et al., 1982; Bellion \& Bolbot, 1983; Brooke et al., 1987), very little is known about the properties and regulation of this enzyme in methylotrophic bacteria. This paper describes the purification, location and regulation of GS from Hyphomicrobium $\mathrm{X}$.

\section{Methods}

Organism and growth conditions. Hyphomicrobium $\mathrm{X}$ was maintained and grown in batch culture as described previously (Harder et al., 1973). In order to ensure (i) expression of GS, the growth medium contained methanol $(40 \mathrm{mM})$ as the carbon source and $\mathrm{KNO}_{3}(10 \mathrm{mM})$ as the nitrogen source; (ii) that GS was predominantly in the adenylylated form ( $70 \%$ adenylylated), the standard growth medium was used to which $\left(\mathrm{NH}_{4}\right)_{2} \mathrm{SO}_{4}(100 \mathrm{mM})$ was added $1 \mathrm{~min}$ before harvesting the cells; (iii) that GS was predominantly in the deadenylylated form $(13 \%$ adenylylated), the nitrate concentration in the medium was lowered to $0.5 \mathrm{~mm}$. All media were inoculated with cells grown to the midexponential phase of growth in the same medium. Growth was followed by measuring the optical density at $430 \mathrm{~nm}$; bacteria were harvested in the mid-exponential phase of growth, washed once with $50 \mathrm{mM}$-Tris/ $\mathrm{HCl}$ buffer, $\mathrm{pH} 7.5$ and used immediately.

Preparation of cell-free extracts. Cells were suspended $(25 \%, w / v)$ in cold $50 \mathrm{~mm}$-Tris/ $\mathrm{HCl}$ buffer, $\mathrm{pH} 7 \cdot 5$. Ice-cold cell suspensions were disrupted by sonication for $10 \times 30 \mathrm{~s}(6 \mu \mathrm{m}$ peak) alternating with $30 \mathrm{~s}$ cooling periods. Cell debris was removed by centrifugation $(30000 \mathrm{~g}$; 30 min at $4{ }^{\circ} \mathrm{C}$ ) and the supernatant obtained was used as the crude cellfree extract.

Enzyme assays. All enzyme activities were measured at $30^{\circ} \mathrm{C}$. The observed enzyme rates were proportional to the amount of extract added and were linear for at least $3 \mathrm{~min}$. The enzyme activities are given as $\mu$ mols product $\min ^{-1}$ (mg protein) $)^{-1}$.

GS [L-glutamate : ammonia ligase (ADP-forming); EC 6.3.1.2] was measured using either the $\gamma$-glutamyltransferase assay or the biosynthetic assay. (i) GS $\gamma$-glutamyltransferase activity was measured by the method of Bender et al. (1977), except that the $\mathrm{pH}$ was adjusted to 6.7 and the incubation was at $30^{\circ} \mathrm{C}$. (ii) The GS biosynthetic assay was a discontinuous assay which measured the release of $P_{i}$ from ATP. The assay system was a modification of that described by Murrell \& Dalton (1983). The $\mathrm{pH}$ of the buffer was increased to 7.5 and the concentration of ATP increased to $5 \mu \mathrm{mol} \mathrm{ml}^{-1}$. Samples $(200 \mu \mathrm{l})$ were removed from the reaction mixtures at appropriate time intervals and the $P_{i}$ released was measured by the method of Baginski et al. (1967). The amount of $P$ released from ATP was determined from a standard curve prepared by using known concentrations of $P_{i}$ and following the same analysis procedure. Published assays were used to assay hydroxypyruvate reductase (EC 1 1 1 1 81) by the method of Blackmore \& Quayle (1970), and $\mathrm{NAD}^{+}$-dependent formate dehydrogenase (EC 1.2.1.2) by the method of Johnson \& Quayle (1964) as modified by Harder et al. (1973). Succinate dehydrogenase (EC 1.35.99.1), the NADH oxidase system and GOGAT (EC 1.4.1.14) were assayed as described by Meers $e t$ al. (1970).

Protein estimations. Protein concentrations in cell-free extracts were measured using the Lowry method with bovine serum albumin as standard.

Sucrose gradient centrifugation. Sucrose gradients $(20-60 \%, \mathrm{w} / \mathrm{v})$ were prepared in $50 \mathrm{~mm}$-Tris/ $\mathrm{HCl}$ buffer containing mercaptoethanol ( $2 \mathrm{mM})$ and $\mathrm{MnCl}_{2}(1 \mathrm{mM})$ by successively layering less dense sucrose solution $(2 \mathrm{ml})$ in $10 \%$ increments. Crude cell-free extracts $(1.4 \mathrm{ml})$ were layered onto the top of the gradient and centrifuged in a Beckman L8 ultracentrifuge with a swinging bucket SW41 Ti rotor. After centrifugation the gradients were fractionated (from the top) into aliquots $(0.5 \mathrm{ml})$. The sucrose concentration was determined using a refractometer. A calibration curve was constructed from sucrose solutions of known concentrations.

Enzyme purification.

All procedures were carried out at $4{ }^{\circ} \mathrm{C}$. The buffer used throughout was $50 \mathrm{~mm}$-Tris/HCl, pH 7.5, containing mercaptoethanol (2 mM), 
$\mathrm{MnCl}_{2}(1 \mathrm{mM})$ and EDTA (0.5 mM). Differential sedimentation was carried out using a Beckman L8 ultracentrifuge with a fixed-angle type 65 rotor into which rigid screw cap polycarbonate tubes $(10 \mathrm{ml})$ were placed.

Step 1 . Crude cell-free extracts $(4 \mathrm{ml})$ were centrifuged at $100000 \mathrm{~g}$ for $50 \mathrm{~min}$ and the supernatant (S1) was retained.

Step 2. The $\mathrm{S} 1$ fraction was centrifuged at $107000 \mathrm{~g}$ for $140 \mathrm{~min}$, and the supernatant (S2) was discarded. The pellet (P2) was gently resuspended in the buffer and allowed to solubilize for $18 \mathrm{~h}$ at $4{ }^{\circ} \mathrm{C}$. Particulate material was removed by a slow speed centrifugation $(35000 \mathrm{~g}, 10 \mathrm{~min})$ and the supernatant $(\mathrm{RP} 2)$ retained.

Step 3. The RP2 fraction was subjected to a repeat of step 2 to give a second resuspended pellet (RP22).

Step 4. RP22 was loaded onto a column of Blue Sepharose CL-6B $(1.0 \times 2.0 \mathrm{~cm})$ prepared for use according to the manufacturer's instructions, packed at a flow rate of $40 \mathrm{ml} \mathrm{h}^{-1}$ and equilibrated with buffer. The column was washed at a flow rate of $30 \mathrm{ml} \mathrm{h}^{-1}$ with buffer containing $\mathrm{NaCl}(1 \mathrm{M})$ to remove any weakly bound protein, then eluted by buffer containing ATP ( $20 \mathrm{mM})$. Fractions which contained GS activity were pooled.

Step 5 . The pooled active fractions were separated from contaminating ATP by loading onto a column of Sephadex G-25 $(2 \times 6 \mathrm{~cm})$. The column was equilibrated with buffer and eluted at a flow rate of $120 \mathrm{ml}$ $\mathrm{h}^{-1}$. Fractions containing activity were pooled and, if necessary, concentrated by forced dialysis against dry carboxymethylcellulose to a protein concentration of $0 \cdot 1-0.5 \mathrm{mg} \mathrm{ml}^{-1}$. Enzyme preparations from step 3 and step 5 could be stored at $-20^{\circ} \mathrm{C}$ for up to 6 months and the activity retained was $90 \pm 5 \%$ of the original activity.

\section{Electrophoretic methods.}

All gels consisted of a stacking gel on top of a separating gel which were prepared and run using a discontinuous buffer system (Laemmli, 1970). Electrophoresis was at a constant current of $20 \mathrm{~mA}$ through the stacking gel and $40 \mathrm{~mA}$ through the separating gel. The apparatus was run at room temperature with denaturing SDS-gels and at $4{ }^{\circ} \mathrm{C}$ for the non-denaturing gels. A heat exchanger was used in the lower buffer chamber in order to minimize the increase in temperature during the separation. Denaturing SDS-gels were used to determine the purity of the enzyme preparation and size of enzyme subunits. Non-denaturing gels were used to estimate the molecular mass of the native enzyme and for the activity stain.

Denaturing ( $S D S-P A G E$ ). This was done as described by Laemmli \& Favre (1973), with the following calibration protein reference markers: bovine serum albumin (molecular mass $66 \mathrm{kDa}$ ), chicken egg albumin (45 kDa), rabbit muscle glyceraldehyde-3-phosphate dehydrogenase, subunit $(36 \mathrm{kDa})$, bovine erythrocyte carbonic acid anhydrase $(29 \mathrm{kDa})$, bovine pancreas trypsinogen $(24 \mathrm{kDa})$, soybean trypsin inhibitor (20.1 kDa) and bovine milk $\alpha$-lactalbumin $(14 \cdot 2 \mathrm{kDa})$.

Non-denaturing gels (minus SDS). These contained, in the separating gels, either 3.0 or $5.5 \%(\mathrm{w} / \mathrm{v})$ acrylamide, and in the stacking gel, $1.4 \%$ $(w / v)$ acrylamide. Samples were prepared by the addition of an equal volume of $50 \mathrm{~mm}$-Tris/ $\mathrm{HCl}$ buffer, $\mathrm{pH} 6.7$, containing equal quantities of glycerol and bromophenol blue $(0.025 \%, \mathrm{w} / \mathrm{v})$. The electrode buffer contained Tris $\left(0.6 \mathrm{~g} \mathrm{l}^{-1}\right)$ and glycine $\left(2.88 \mathrm{~g} \mathrm{l}^{-1}\right)$ at $\mathrm{pH} 8.3$. The calibration protein reference markers used were: horse spleen ferritin (trimer molecular mass $1428.9 \mathrm{kDa}$, dimer $952.6 \mathrm{kDa}$ and monomer $476.3 \mathrm{kDa}$ ); horse spleen apoferritin (dimer $886 \mathrm{kDa}$ and monomer $443 \mathrm{kDa}$ ), Jack bean urease (tetramer $480 \mathrm{kDa}$ and dimer $240 \mathrm{kDa}$ ), bovine serum albumin (dimer $132 \mathrm{kDa}$ and monomer $66 \mathrm{kDa}$ ), chicken egg albumin $(45 \mathrm{kDa})$ and bovine erythrocyte carbonic acid anhydrase $(29 \mathrm{kDa})$. All gels, except those for demonstration of activity, were stained with Coomassie Brilliant Blue.

Activity stain. GS activity was detected using the $\gamma$-glutamyltransferase reaction mixture previously described except that the $\mathrm{pH}$ was increased to 7.5. Gels were removed from the PAGE apparatus and rinsed in ice-cold $0.1 \mathrm{M}$-Tris/ $\mathrm{HCl}$ buffer, $\mathrm{pH} 7.5$, before incubation in the reaction mixture for $45 \mathrm{~min}$ at $30^{\circ} \mathrm{C}$. The gel was incubated further in ferric chloride reagent for up to $15 \mathrm{~min}$ to allow the bands to develop. The activity bands were stable for only 5-10 $\mathrm{min}$, so $R_{F}$ values were measured immediately.

Control of covalent modification. Crude cell-free extracts of GS in the deadenylylated form were prepared and incubated at $30^{\circ} \mathrm{C}$ in the presence and absence of glutamine $(5 \mathrm{mM}), \mathrm{P}_{\mathrm{i}}(20 \mathrm{mM}), \mathrm{Mn}^{2+}(20 \mathrm{mM})$ and ATP (1 mM). These incubation mixtures were sampled at known time intervals and the adenylylation state measured with the $\gamma$ glutamyltransferase assay.

Inhibitor studies. The purified enzyme was preincubated in the presence of various products of glutamine metabolism (1.5 and $10 \mathrm{mM})$ in the standard biosynthetic assay mixture minus ATP. The adenylylated enzyme was assayed in the presence of $\mathrm{Mn}^{2+}$ and the deadenylylated enzyme in the presence of $\mathrm{Mg}^{2+}$ at their respective $\mathrm{pH}$ optima. Enzyme activity was measured after addition of ATP to the reaction mixture. Enzyme activities were compared with the control activity of the enzyme in the absence of any inhibitor.

\section{Results and Discussion}

\section{Purification of the enzyme}

The results of a typical purification are shown in Table 1 and Fig. 1. The enzyme was purified 91.2 fold with a $31.4 \%$ yield. The specific activity of the purified enzyme was $44.7 \mu \mathrm{mol} \mathrm{min}^{-1}$ (mg protein) ${ }^{-1}$.

\section{Purity of the enzyme}

With non-denaturing PAGE a single band was developed which showed the enzyme had been purified to homogeneity. When the gels were stained for GS activity a single band was observed with an $R_{F}$ value identical to that of the pure enzyme. (Data not shown.)

\section{Location of $G S$ within the cell}

The crude cell-free extract was fractionated by sedimentation through a sucrose gradient $(20-60 \%, \mathrm{w} / \mathrm{v})$. When the fractions were monitored for absorbance at 260 and $280 \mathrm{~nm}$, three peaks were revealed (Fig. $2 a$ ). Measurements for GS and GOGAT activity showed that the main activities of the two enzymes were recovered from the gradient in different fractions and that these activities were not associated with the fractions containing membrane-associated enzymes (Fig. $2 b$ ). Therefore the rapid differential sedimentation of GS activity in the purification procedure was unlikely to be due to complex formation with GOGAT (Streicher \& Tyler, 1980) or an association with the cell membrane (Kleinschmidt \& 


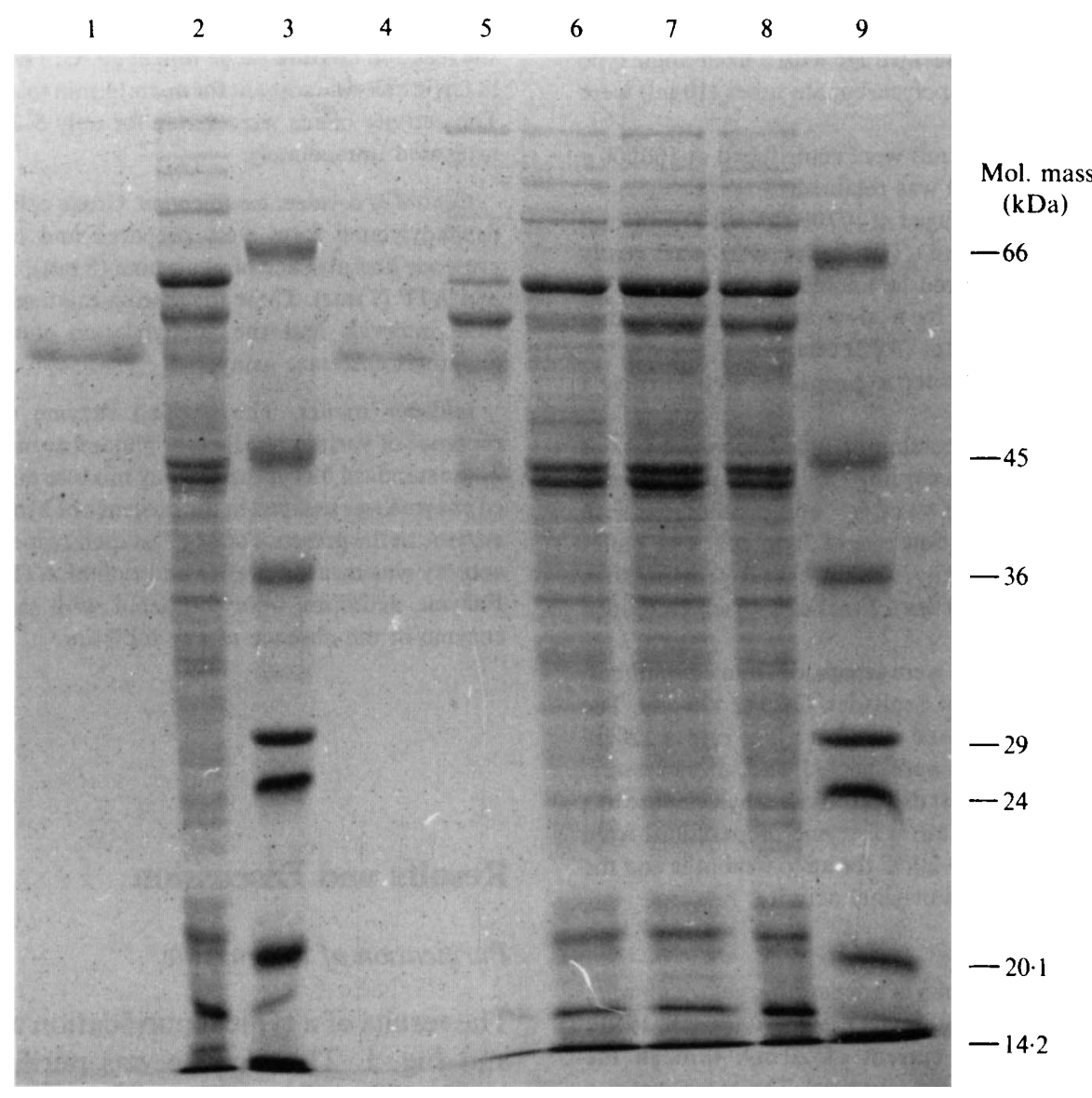

Fig. 1. SDS-polyacrylamide gel of the purification stages of GS. A $10 \%(w / v)$ SDS-polyacrylamide gel was prepared and protein samples electrophoresed as described in Methods. Protein was visualized by staining with Coomassie Brilliant Blue. Protein markers (molecular mass values indicated) were as described in Methods. Tracks (3) and (9), protein markers; (2) and (8), crude cell-free extract (100 $\mu \mathrm{g}) ;(7)$ S1 $(100 \mu \mathrm{g})$; (6) S2 $(100 \mu \mathrm{g})$; (5) RP22 (35 $\mu \mathrm{g})$; (4) Blue Sepharose fraction $(4 \mu \mathrm{g})$; (1) Blue Sepharose fraction $(8 \mu \mathrm{g})$.

Table 1. Purification of GS from Hyphomicrobium $X$

All purification steps were done as described in Methods. Enzyme activity was determined using the $\gamma$-glutamyltransferase assay.

\begin{tabular}{|c|c|c|c|c|c|c|}
\hline $\begin{array}{l}\text { Purification } \\
\text { stage }\end{array}$ & $\begin{array}{l}\text { Vol. } \\
(\mathrm{ml})\end{array}$ & $\begin{array}{l}\text { Total } \\
\text { protein } \\
(\mathrm{mg})\end{array}$ & $\begin{array}{c}\text { Total } \\
\text { activity } \\
\left(\mu \mathrm{mol} \mathrm{min}^{-1}\right)\end{array}$ & $\begin{array}{c}\text { Specific } \\
\text { activity } \\
{\left[\mu \text { mol }^{2} \text { min }^{-1}\right.} \\
\left.(\mathrm{mg} \text { protein })^{-1}\right]\end{array}$ & $\begin{array}{l}\text { Purification } \\
\text { (-fold) }\end{array}$ & $\begin{array}{c}\text { Yield } \\
(\%)\end{array}$ \\
\hline $\begin{array}{l}\text { Crude } \\
\text { extract }\end{array}$ & 8 & 105.6 & $51 \cdot 2$ & 0.49 & 1 & 100 \\
\hline $\begin{array}{l}\text { RP22 } \\
\text { fraction }\end{array}$ & 5 & 17 & $50 \cdot 65$ & 3.00 & $6 \cdot 1$ & 98.9 \\
\hline $\begin{array}{l}\text { Blue Sepharose } \\
\text { chromatography } \\
\text { Sephadex G-25 }\end{array}$ & 2 & $0 \cdot 37$ & $10 \cdot 04$ & $27 \cdot 3$ & $55 \cdot 71$ & $19 \cdot 6$ \\
\hline filtration & $3 \cdot 2$ & 0.36 & 16.06 & $44 \cdot 7$ & $91 \cdot 2$ & 31.4 \\
\hline
\end{tabular}

Kleiner, 1978; Florencio \& Romos, 1985). When the experiment was repeated with a crude cell-free extract which had been preincubated with DNAase I (150 $\mu \mathrm{g}$ $\mathrm{ml}^{-1}$ ) at $37^{\circ} \mathrm{C}$ for $10-15 \mathrm{~min}$ the total absorbance at
$260 \mathrm{~nm}$ recovered from the sucrose gradient was reduced significantly but the activity peaks were in identical positions, the GS activity sedimented equally well and the final enzyme purification and yield was comparable 

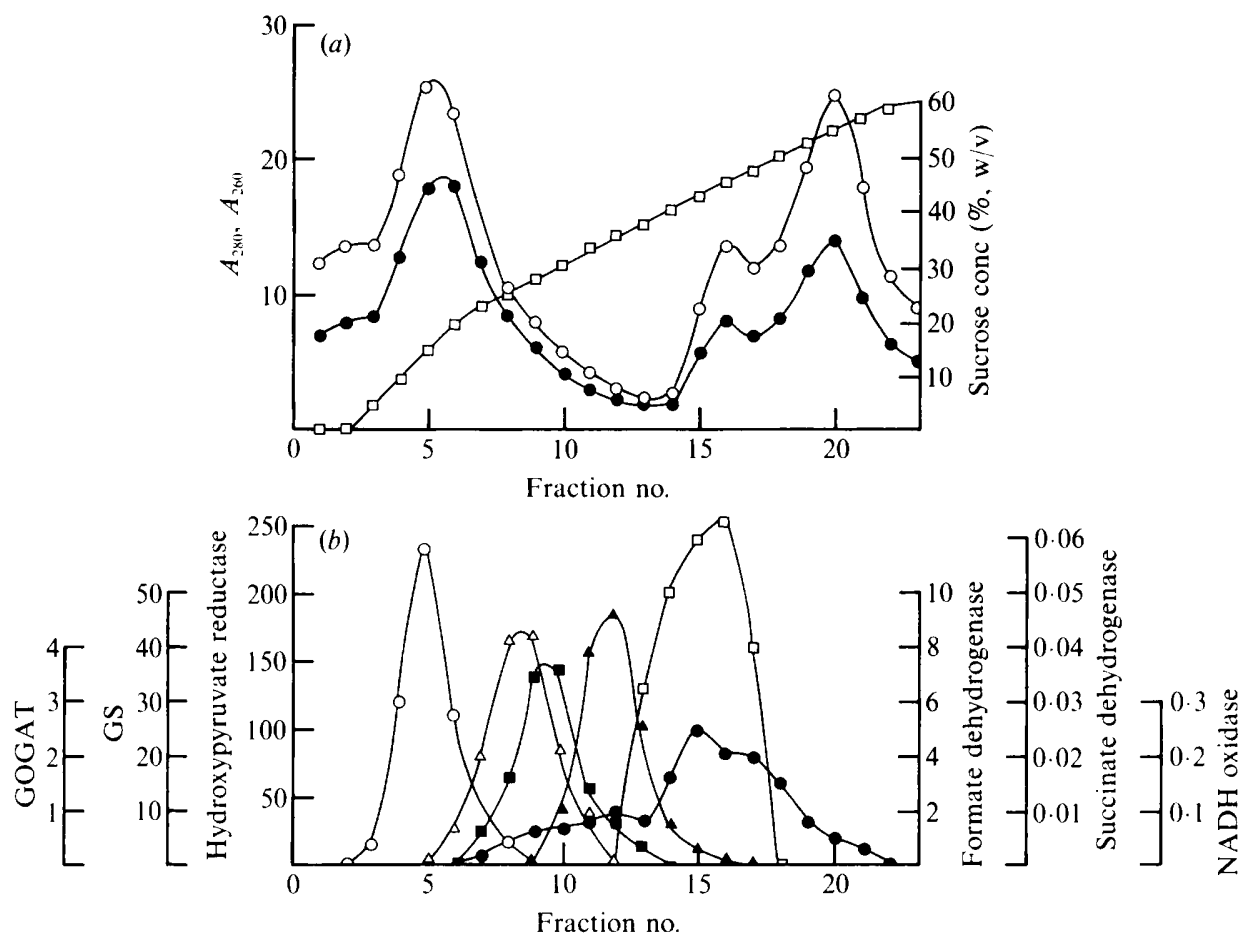

Fig. 2. Ultracentrifugation of crude cell-free extracts on a $20-60 \%(\mathrm{w} / \mathrm{v})$ sucrose gradient. Crude cell-free extract from Hyphomicrobium $\mathrm{X}$ grown in batch culture on methanol $(40 \mathrm{mM})$ and $\mathrm{KNO}_{3}(10 \mathrm{mM})$ was subjected to ultracentrifugation as described in Methods. (a) Absorbance at $280 \mathrm{~nm}(\bigcirc)$ and at $260 \mathrm{~nm}(\odot) ; \square$, sucrose concentration. (b) Enzyme activites [ $\mu$ mol product $\min ^{-1}$ (mg protein) ${ }^{-1}$; see Methods] in the fractions shown in $(a)$. $\bigcirc$, Hydroxypyruvate reductase; $\triangle$, formate dehydrogenase; $\square$, GOGAT; $\triangle$, GS;, , NADH oxidase; $\square$, succinate dehydrogenase.

to that obtained without DNAase treatment (data not shown). Thus in Hyphomicrobium $\mathrm{X}$ the enzyme is cytoplasmic and the rapid differential sedimentation cannot be explained by an association with DNA or membranes.

\section{Molecular mass}

The molecular mass of the purified native enzyme was estimated using non-denaturing PAGE to be $638 \mathrm{kDa}$. This value is similar to values cited for GS from other bacteria (Table 2). When SDS-denaturing gels were used, two protein bands were observed with molecular masses of 52.5 and $53.7 \mathrm{kDa}$. Two protein bands of similar molecular mass have been reported with GS from a number of different bacteria (Pseudomonas putida, Streicher \& Tyler, 1980; Caulobacter crescentus, Ely et al., 1978; Escherichia coli and Klebsiella aerogenes, Bender \& Streicher, 1979). Initially, the presence of the bands was thought to reflect a slight difference in the electrophoretic properties of the adenylylated and deadenylylated subunits. However, not all bacteria which possess a GS subject to covalent modification show subunits of different electrophoretic mobilities (Azotobacter vinelan- dii, Kleinschmidt \& Kleiner, 1978; Nitrobacter agilis, Kumar \& Nicholas, 1984; Rhodomicrobium vannielii, Caballero et al., 1987; Vibrio alginolyticus, Bodusing et al., 1985). This suggests that the two bands are not a reflection of covalent modification of the GS subunits. When an average molecular mass was taken from the two protein bands $(53.1 \mathrm{kDa})$ and compared with the molecular mass of the native enzyme $(638 \mathrm{kDa})$, the enzyme was shown to be an oligomeric enzyme with twelve subunits (Table 2). Thus the size and structure of the GS purified from Hyphomicrobium $\mathrm{X}$ was consistent with that reported for the majority of the GS enzymes purified from prokaryotic sources.

\section{Kinetic properties}

The purified deadenylylated enzyme was used to measure the enzyme activity in the $\gamma$-glutamyltransferase and biosynthetic assays over a range of substrate concentrations. Double reciprocal plots showed that the enzyme followed Michaelis-Menten kinetics. The apparent $K_{\mathrm{m}}$ values for hydroxylamine $(7.0 \mathrm{~mm})$ and glutamine $(5.0 \mathrm{~mm})$ were similar to those reported for GS from the methanotroph Methylococcus capsulatus strain 


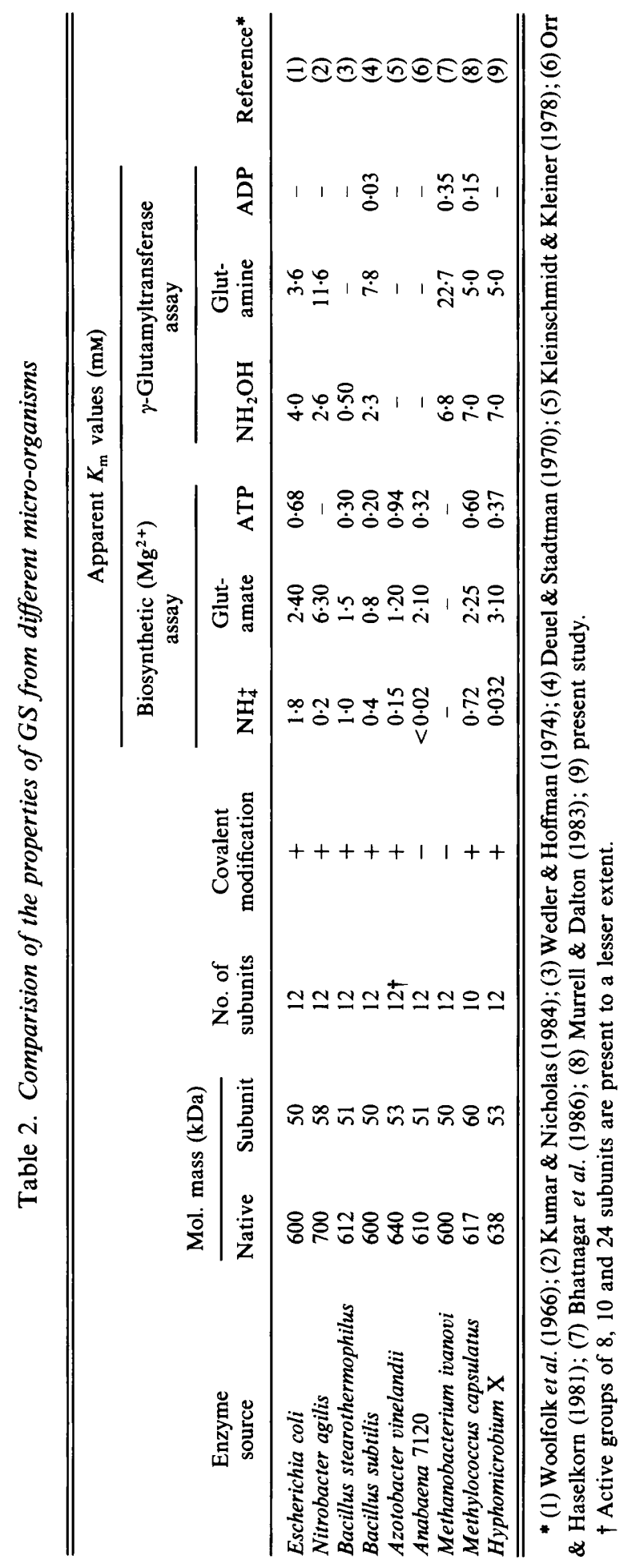


Table 3. Effect of certain metabolites on the adenylylation state of $G S$ in crude cell-free extracts

Cell-free extracts of Hyphomicrobium $\mathrm{X}$ grown in batch culture on methanol $(20 \mathrm{mM})$ and $\left(\mathrm{NH}_{4}\right)_{2} \mathrm{SO}_{4}(1 \mathrm{mM})$ were incubated in the presence or absence of glutamine $(5 \mathrm{mM}), \mathrm{P}_{\mathrm{i}}(20 \mathrm{mM}), \mathrm{Mn}^{2+}$ (20 mM) and ATP (1 mM). Extracts were sampled and assayed for their adenylylation state.

\begin{tabular}{lcc}
\hline \hline & \multicolumn{2}{c}{ Adenylylation state $(\%)$} \\
\cline { 2 - 3 } Time & $\begin{array}{c}\text { Incubation in presence } \\
\text { of metabolites }\end{array}$ & $\begin{array}{c}\text { Incubation in absence } \\
\text { of metabolites }\end{array}$ \\
\hline 0 & $4 \cdot 3$ & $4 \cdot 3$ \\
10 & 20 & $4 \cdot 6$ \\
20 & $26 \cdot 8$ & $7 \cdot 9$ \\
30 & 30 & 5 \\
40 & 33 & 5 \\
60 & 34 & $5 \cdot 7$ \\
70 & $34 \cdot 3$ & $5 \cdot 4$ \\
\hline \hline
\end{tabular}

Bath (Murrell \& Dalton, 1983). An apparent $K_{\mathrm{m}}$ for ADP could not be determined due to a high endogenous rate. At present there is no explanation for this high endogenous rate. The kinetic data for the biosynthetic assay (see Table 2) showed that the $K_{\mathrm{m}}$ value for ammonia $(32 \mu \mathrm{M})$ was significantly lower than that for either glutamate $(3.1 \mathrm{~mm})$ or ATP $(0.37 \mathrm{~mm})$. This is in agreement with the physiological role of GS in the assimilation of ammonia under nitrogen-limited conditions. This value was lower than many reported values $(0.1-1.0 \mathrm{mM})$ but not exceptional, since the apparent $K_{\mathrm{m}}$ for ammonia of GS from the cyanobacterium Anabaena 7120 was $20 \mu \mathrm{M}$ (Orr \& Haselkorn, 1981).

\section{Regulation of $G S$}

We have reported previously (Duchars \& Attwood, 1989) that in Hyphomicrobium X GS synthesis is repressed when nitrogen is available to the cell in a plentiful and readily utilizable form and induced when nitrogen is limiting for growth. Moreover, GS activity is controlled by the system of covalent modification involving adenylylation and deadenylylation (Brooke et al., 1987). This control mechanism itself is regulated in many bacteria via a complex cascade system that is stimulated and inhibited by specific metabolites (Brown et al., 1971; Mangum et al., 1973). Crude cell-free extracts containing GS in the deadenylylated state were incubated at $30^{\circ} \mathrm{C}$ in the presence and absence of glutamine, $\mathrm{P}_{\mathrm{i}}, \mathrm{Mn}^{2+}$ and ATP and the adenylylation state of the enzyme was measured. The adenylylation state of the enzyme increased from 4 to $34 \%$ over a 70 min incubation period (Table 3) in the presence of metabolites, compared to no change in the adenylylation state when incubated under the same conditions without added metabolites. This
Table 4. Effect of addition of divalent cations to the standard $\gamma$-glutamyltransferase assay

Purified adenylylated and deadenylylated enzyme were incubated in the standard $\gamma$-glutamyltransferase assay mixture in the presence and absence of extra divalent cations. Activity of the adenylylated enzyme in the standard assay mixture alone was $2.86 \mu \mathrm{mol} \mathrm{min}^{-1}$ (mg protein $)^{-1}$ and of the deadenylylated enzyme $3.22 \mu \mathrm{mol} \mathrm{min}^{-1}$ (mg protein $)^{-1}$.

\begin{tabular}{|c|c|c|c|c|c|c|c|}
\hline \multirow{3}{*}{$\begin{array}{l}\text { Divalent } \\
\text { cation }\end{array}$} & \multirow{3}{*}{$\begin{array}{r}\text { Concn } \\
(\mathrm{mM})\end{array}$} & \multicolumn{6}{|c|}{ Inhibition $(\%)$} \\
\hline & & \multicolumn{3}{|c|}{$\begin{array}{l}\text { Adenylylated } \\
\text { enzyme }\end{array}$} & \multicolumn{3}{|c|}{$\begin{array}{l}\text { Deadenylylated } \\
\text { enzyme }\end{array}$} \\
\hline & & 3 & 6 & 10 & 3 & 6 & 10 \\
\hline $\mathrm{Mn}^{2+}$ & & 1 & 1 & 4 & 3 & 6 & 5 \\
\hline $\mathrm{Mg}^{2+}$ & & 18 & 30 & 38 & 4 & 3 & 8 \\
\hline $\mathrm{Cu}^{2+}$ & & 17 & 29 & 73 & 30 & 50 & 85 \\
\hline $\mathrm{Co}^{2+}$ & & 25 & 42 & 75 & 17 & 39 & 76 \\
\hline $\mathrm{Zn}^{2+}$ & & 25 & 50 & 80 & 22 & 35 & 82 \\
\hline $\mathrm{Ca}^{2+}$ & & 32 & 41 & 54 & 24 & 33 & 48 \\
\hline $\mathrm{Fe}^{2+}$ & & 35 & 70 & 83 & 25 & 55 & 92 \\
\hline
\end{tabular}

suggests that the covalent modification of GS in Hyphomicrobium X can be regulated in a manner similar to that reported for E. coli (Segal \& Stadtman, 1972a, $b$; Ginsburg \& Stadtman, 1973).

\section{Effect of divalent cations on GS activity}

The divalent cation requirement for catalytic activity has been found to depend on the adenylylation state (Kingdom et al., 1967). When the $\gamma$-glutamyltransferase assay was used to measure GS activity with the purified enzyme from Hyphomicrobium $\mathrm{X}$, the results showed that, irrespective of the adenylylation state, none of the divalent cations tested $\mathrm{CCo}^{2+}, \mathrm{Ca}^{2+}, \mathrm{Fe}^{2+}$ or $\left.\mathrm{Zn}^{2+}\right)$, except $\mathrm{Mg}^{2+}$, could replace $\mathrm{Mn}^{2+}$ in the standard assay mixture. When $\mathrm{Mg}^{2+}$ was substituted for $\mathrm{Mn}^{2+}$ the activity was $50 \%$ of that measured in the presence of $\mathrm{Mn}^{2+}$. Furthermore, when divalent cations were added at increasing concentrations $(0-10 \mathrm{mM})$ to a standard assay mixture containing $\mathrm{Mn}^{2+}$, all the divalent cations tested, except $\mathbf{M g}^{2+}$, inhibited to a similar extent both the adenylylated and the deadenylylated form of the enzyme (Table 4). $\mathrm{Mg}^{2+}$ inhibited the adenylylated form of the enzyme only. The effect of adding divalent cations to the more physiologically relevant biosynthetic assay was studied with the partially purified enzyme (RP22 stage), prepared from cells which contained GS predominantly in either the adenylylated or the deadenylylated state. When the activity of the deadenylylated form of the enzyme was measured over the $\mathrm{pH}$ range $6.5-8.5$ with different divalent cations added, activity could be detected only in the presence of $\mathrm{Mg}^{2+}$ and the $\mathrm{pH}$ 

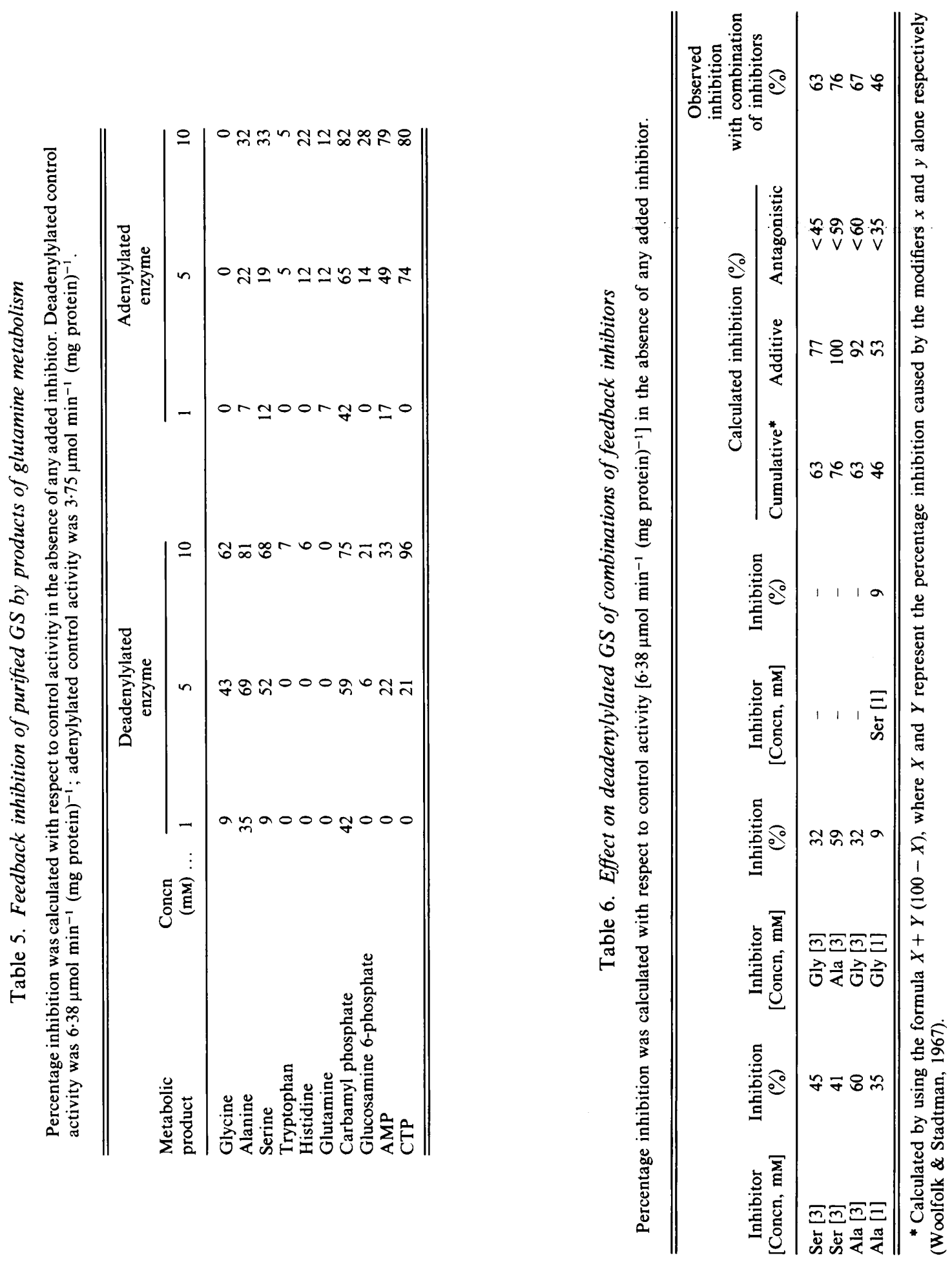
optimum was $7 \cdot 5$. When the experiment was repeated with the enzyme in the adenylylated form, activity could be detected only in the presence of $\mathrm{Mn}^{2+}$ and the $\mathrm{pH}$ optimum was $6 \cdot 7$. Neither the adenylylated nor deadenylylated enzyme showed activity at the pH optimum of the other form of the enzyme. Therefore, the activity of GS purified from Hyphomicrobium $\mathrm{X}$ was controlled by covalent modification and like similar GS from other bacteria the $\mathrm{Mn}^{2+}$ activated biosynthetic assay and the $\mathrm{Mg}^{2+}$-activated biosynthetic assay were specific to the adenylylated and deadenylylated form, respectively. Moreover, the activity of the deadenylylated $\mathbf{M g}^{2+}$ activated form of the enzyme was 1.5 -fold greater than that of the adenylylated $\mathrm{Mn}^{2+}$-activated form when measured at their respective $\mathrm{pH}$ optima. This effect has been reported with GS enzymes purified from other micro-organisms.

\section{Feedback inhibition}

The possibility of feedback regulation of GS by various amino acids and other endproducts of glutamine metabolism was investigated using both purified adenylylated and purified deadenylylated enzyme preparations. Glycine, alanine and serine had a greater inhibitory effect on the deadenylylated enzyme whilst histidine, glutamine and AMP were more inhibitory towards the adenylylated enzyme (Table 5). Both enzyme forms were not inhibited by tryptophan and equally inhibited by carbamyl phosphate, glucosamine 6-phosphate and CTP. From the level of inhibition observed with each inhibitor alone theoretical calculations can be made to predict the percentage inhibition that would be observed when combinations of two or more inhibitors were used and the overall inhibition was additive, antagonistic or cumulative (Woolfolk \& Stadtman, 1967). The results (Table 6) demonstrated that the inhibition observed correlated closely with that predicted for cumulative feedback inhibition of two or more inhibitors. This can be taken as presumptive evidence that there were separate binding sites on the enzyme for each inhibitor and that there were no interactions between the sites (Woolfolk \& Stadtman, 1967; Shapiro \& Stadtman, 1970). The GS from Hyphomicrobium $X$ is subject to feedback inhibition similar to that reported with GS from Gram-positive and other Gram-negative bacteria (Hubbard \& Stadtman, 1967a, b; Wedler et al., 1976). The addition of single endproducts caused partial inhibition whilst the presence of two or more inhibitors had a cumulative effect (Woolfolk \& Stadtman, 1967). Moreover, the adenylylation state of the enzyme affected its susceptibility to feedback inhibitors.
M. G. D. thanks SERC for financial support and Dr S. Andrews for the gift of horse spleen ferritin.

\section{References}

BaGINSKI, E. S., FoA, P. P. \& ZAK, B. (1967). Microdetermination of inorganic phosphate, phospholipids and total phosphate in biological materials. Clinical Chemistry 13, 326-330.

Bellion, E. \& Bolbot, J. R. (1983). Nitrogen assimilation in facultative methylotrophic bacteria. Current Microbiology 9, 37-44.

Bender, R. A. \& Streicher, S. L. (1979). Glutamine synthetase. Regulation, adenylylation state and strain specificity analysed by polyacrylamide gel electrophoresis. Journal of Bacteriology 137, 1000-1007.

Bender, R. A., Janssen, K. A., Resnick, A. D., Blumenberg, M., FoOR, F. \& MAGASANIK, B. (1977). Biochemical parameters of glutamine synthetase from Klebsiella aerogenes. Journal of Bacteriology 129, 1001-1009.

Bhatnagar, L., Zeikus, J. G. \& Aubert, J.-P. (1986). Purification and characterization of glutamine synthetase from the archaebacterium Methanobacterium ivanovi. Journal of Bacteriology 165, 638-643.

BlackmoRe, M. A. \& QuaYle, J. R. (1970). Microbial oxidation of oxalate by a route not involving glyoxylate carboligase. Biochemical Journal 118, 53-59.

Bodusing, S. J., BrantT, P. W., RobB, F. T. \& Woods, D. R. (1985). Purification and regulation of glutamine synthetase in a collagenolytic Vibrio alginolyticus strain. Archives of Microbiology 140, 369-374.

Brooke, A. G., Duchars, M. G. \& AtTwOod, M. M. (1987). Nitrogen assimilation in the facultative methylotroph Hyphomicrobium X. FEMS Microbiology Letters 41, 41-45.

Brown, C. M. (1980). Ammonia assimilation and utilization in bacteria and fungi. In Microorganisms and Nitrogen Sources, pp. 511538. Edited by J. W. Payne. New York: Academic Press.

Brown, M. S., Segal, A. \& Stadtman, E. R. (1971). Modulation of glutamine synthetase adenylylation and deadenylylation is mediated by metabolic transformation of the $\mathrm{P}_{\mathrm{II}}$-regulatory protein. Proceedings of the National Academy of Sciences of the United States of America 68, 2949-2943.

Caballero, P., Romero, F. \& Roldan, J. M. (1987). Purification and characterisation of glutamine synthetase from Rhodomicrobium vannielii. FEMS Microbiology Letters 48, 15-17.

DALTON, H. (1979). Utilization of inorganic nitrogen by microbial cells. International Reviews of Biochemistry 21, 227-266.

Deuel, T. F. \& Stadtman, E. R. (1970). Some kinetic properties of Bacillus subtilis glutamine synthetase. Journal of Biological Chemistry 245, 5206-5213.

Duchars, M. G \& ATTwood, M. M. (1989). The influence of C:N ratio in the growth medium on the cellular composition and regulation of enzyme activity in Hyphomicrobium X. Journal of General Microbiology 135, 787-793.

Ely, B., Amarasinghe, A. B. C. \& Bender, R. A. (1978). Ammonia assimilation and glutamate formation in Caulobacter crescentus. Journal of Bacteriology 133, 225-230.

FLoRENCIO, F. J. \& RoMOs, J. L. (1985). Purification and characterization of glutamine synthetase from the unicellular cyanobacterium Anacystis nidulans. Biochimica et Biophysica Acta 838, 39-48.

GINSBURG, A. (1969). Conformational changes in glutamine synthetase from Escherichia coli. II. Some characteristics of the equilibrium binding of feedback inhibitors to the enzyme. Biochemistry 8, 17261740

Ginsburg, A. \& Stadtman, E. R. (1973). Regulation of glutamine synthetase in Escherichia coli. In The Enzymes of Glutamine Metabolism, pp. 9-44. Edited by S. Prusiner \& E. R. Stadtman. New York: Academic Press.

Ginsburg, A., Yeh, J., Henning, S. B. \& Denten, M. D. (1970). Some effects of adenylylation on the biosynthetic properties of the glutamine synthetase from Escherichia coli. Biochemistry 9, 633-649. 
HARDER, W. \& ATTWOOD, M. M. (1978). Biology, physiology and biochemistry of hyphomicrobia. Advances in Microbial Physiology 17, 303-359.

Harder, W., Attwood, M. M. \& Quayle, J. R. (1973). Methanol assimilation by Hyphomicrobium sp. Journal of General Microbiology $78,155-163$.

Hubbard, J. S. \& Stadtman, E. R. (1967a). Regulation of glutamine synthetase. V. Partial purification and properties of glutamine synthetase of Bacillus licheniformis. Journal of Bacteriology 94, 10071015 .

Hubbard, J. S. \& StadtMan, E. R. (1976b). Regulation of glutamine synthetase. VI. Interactions of inhibitors for Bacillus licheniformis glutamine synthetase. Journal of Bacteriology 94, 1016-1024.

Johnson, P. A. \& QuAYLE, J. R. (1964). Microbial growth on $\mathrm{C}_{1}$ compounds. 6. Oxidation of methanol, formaldehyde and formate by methanol-grown Pseudomonas AMI. Biochemical Journal 93, 281290.

Kingdom, H. S., Shapiro, B. M. \& Stadtman, E. R. (1967). Regulation of glutamine synthetase. VIII. ATP:glutamine synthetase: an enzyme that catalyses alterations in the regulatory properties of glutamine synthetase. Proceedings of the National Academy of Sciences of the United States of America 58, 1703-1714.

Kingdom, H. S., Hubbard, J. \& Stadtman, E. R. (1968). Regulation of glutamine synthetase. XI. The nature and implications of a lag phase in the Escherichia coli glutamine synthetase reaction. Biochemistry 7 , 2136-2142.

KLeINSCHMIDT, J. A. \& KLeINER, D. (1978). The glutamine synthetase from Azotobacter vinelandii. purification, characterisation, regulation and localisation. European Journal of Biochemistry 89, 51-60.

KumaR, S. \& Nicholas, D. J. D. (1984). Purification, properties and regulation of glutamine synthetase from Nitrobacter agilis. Journal of General Microbiology 130, 959-966.

LAEMMLI, U. K. (1970). Cleavage of structural proteins during the assembly of the head of bacteriophage T4. Nature, London 227, 680685.

LAEmmli, U. K. \& FAVRe, K. (1973). Maturation of the head of bacteriophage T4. 1. DNA packaging events. Journal of Molecular Biology 80, 575-599.

Loginova, N. V., Govorukhina, N. I. \& Trotsenko, Y. A. (1982). Enzymes of the assimilation of ammonium in bacteria with various pathways of $C_{1}$ metabolism. Mikrobiologiya 51, 38-42 (English translation).

Mangum, J. H., Magni, G. \& Stadtman, E. R. (1973). Regulation of glutamine synthetase adenylylation and deadenylylation by the enzymatic uridylylation and deadenylylation of the $P_{I I}$ regulatory protein. Archives of Biochemistry and Biophysics 158, 514-525.

Meers, J. L., Tempest, D. W. \& Brown C. M. (1970). Glutamine (amide) :2-oxoglutarate aminotransferase oxido-reductase (NADP): an enzyme involved in the synthesis of glutamate by some bacteria. Journal of General Microbiology 64, 187-194.

Murrell, J. C. \& Dalton, H. (1983). Purification and properties of glutamine synthetase from Methylococcus capsulatus (Bath). Journal of General Microbiology 129, 1187-1196.

ORR, J. \& HASELKORN, R. (1981). Kinetics and inhibition studies of glutamine synthetase from the cyanobacterium Anabaena 7120. Journal of Biological Chemistry 256, 13099-13104.
Segal, A. \& Stadtman, E. R. (1972a). Effects of cobaltous ion on various catalytic parameters and on heterologous subunit interactions of Escherichia coli glutamine synthetase. Archives of Biochemistry and Biophysics 152, 356-366.

Segal, A. \& StadTMan, E. R. (1972b). Variation of the conformational status of Escherichia coli glutamine synthetase by interactions with different divalent cations. Archives of Biochemistry and Biophysics 152, 367-377.

Segal, A., Brown, M. S. \& Stadtman, E. R. (1974). Metabolite regulation of the state of adenylylation of glutamine synthetase. Archives of Biochemistry and Biophysics 161, 319-327.

Shapiro, B. M. \& Stadtman, E. R. (1967). Regulation of glutamine synthetase. IX. Reactivity of the sulfhydryl groups of the enzyme from Escherichia coli. Journal of Biological Chemistry 242, 5069-5079.

Shapiro, B. M. \& StadtMan, E. R. (1970). The regulation of glutamine synthesis in microorganisms. Annual Review of Microbiology 24, 501 524.

Shishinina, V. N. \& Trotsenko, Y. A. (1979). Pathways of ammonia assimilation in obligate methane utilizers. FEMS Microbiology Letters 5, 187-191.

Stadtman, E. R., Ginsburg, A., Ciardi, E., Yeh, S., Hennig, B. \& ShapIRo, B. M. (1970). Multiple molecular forms of glutamine synthetase produced by enzyme catalysed adenylylation and deadenylylation reactions. Advances in Enzyme Regulation 8, 99-118.

Streicher, S. L. \& TYler, B. (1980). Purification of glutamine synthetase from a variety of bacteria. Journal of Bacteriology 142, 6978.

Tempest, D. W., Meers J. L. \& Brown, C. M. (1973). Glutamate synthase (GOGAT): a key enzyme in the assimilation of ammonia by prokaryotic organisms. In The Enzymes of Glutamine Meiabolism, pp. 167-182. Edited by S. Prusiner \& E. R. Stadtman. New York: Academic Press.

TYLER, B. (1978). Regulation of the assimilation of nitrogenous compounds. Annual Review of Biochemistry 47, 1127-1162.

Valentine, R. C., Shapiro, B. M. \& Stadtman, E. R. (1968). Regulation of glutamine synthetase. XII. Electron microscopy of the enzyme from Escherichia coli. Biochemistry 7, 2143-2152.

WedLeR, F. C. \& Hoffman, F. M. (1974). Glutamine synthetase of Bacillus stearothermophilus. I. Purification and basic properties. Biochemistry 13, 3207-3214.

Wedler, F. C., Carfi, J. \& Ashour, A. E. (1976). Glutamine synthetase of Bacillus stearothermophilus. Regulation, site interactions and functional information. Biochemistry 15, 1749-1755.

Woolfolk, C. A. \& Stadtman, E. R. (1967). Regulation of glutamine synthetase. III. Cumulative feedback inhibition of glutamine synthetase from Escherichia coli. Archives of Biochemistry and Biophysics 118, 736-755.

Woolfolk, C. A., Shapiro, B. M. \& Stadtman, E. R. (1964). Cumulative feedback inhibition in the multiple end product regulation of glutamine synthetase in Escherichia coli. Biochemical and Biophysical Research Communications 17, 313-319.

Woolfolk, C. A., Shapiro B. M. \& Stadtman, E. R. (1966). Regulation of glutamine synthetase. I. Purification and properties of glutamine synthetase from Escherichia coli. Archives of Biochemistry and Biophysics 116, 177-192.

WulfF, K., Mecke, D. \& Holzer, H. (1967). Mechanism of the inactivation of glutamine synthetase from $E$. coli. Biochemical and Biophysical Research Communications 28, 740-745. 